\title{
Influence of Pine Bark Tannin on Bacterial Pathogens Growth and Nitrogen Compounds on Changes in Composted Poultry Litter
}

\section{-Author(s)}

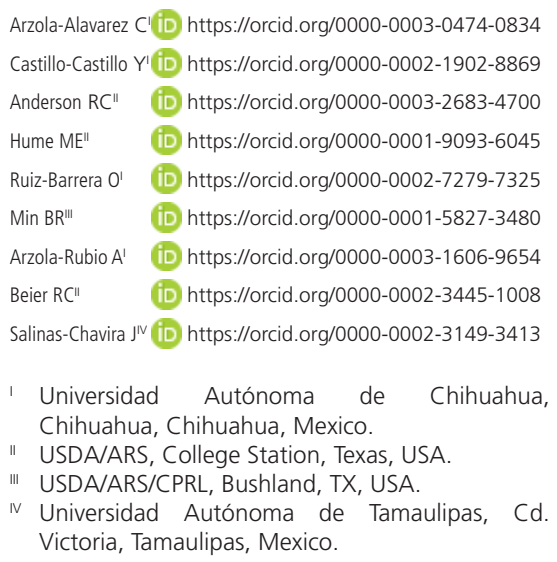

\section{-Mail Address}

Corresponding author e-mail address Jaime Salinas-Chavira

Universidad Autonoma de Tamaulipas Facultad de Medicina Veterinaria y Zootecnia - Nutricion Animal - km. 5 carretera $\mathrm{cd}$. victoria a cd. mante Victoria Tamaulipas 87000 Mexico.

Phone: (0202) 01119992240

Email: jsalinasc@hotmail.com

\section{EKeywords}

Poultry litter, condensed tannins, uric acid, bacterial pathogens.

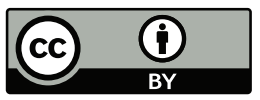

Submitted: 19/July/2019

Approved: 04/February/2020

\section{ABSTRACT}

To study the antimicrobial and uric acid-preserving activity of pine bark tannin on poultry litter composting, antibiotic-free wood chipbased poultry litter was distributed $(11 \mathrm{~g})$ to $50-\mathrm{mL}$ conical centrifuge tubes and immediately amended with $1.3 \mathrm{~mL} 0.4 \mathrm{M}$ sodium phosphate buffer (control) or with $1.3 \mathrm{~mL}$ condensed tannins from pine bark (Pinus palustris; $9 \%$ tannin wt/vol in water). All tubes ( $n=3$ tubes/treatment) were inoculated with a novobiocin and naladixic acid-resistant Salmonella typhimurium (STNN) to achieve $3.0 \log _{10}$ CFU/g and incubated at $37^{\circ} \mathrm{C}$ for 3 days to simulate an initial compost period. Wildtype $E$. coli and the challenge STNN strain as well as concentrations of ammonia, uric acid and urea were measured on days 0 and 3. Pine bark tannin treatment decreased $(p<0.01)$ STNN populations in the litter by 0.6 log units compared to the controls. Wildtype $E$. coli populations were unaffected by tannin treatment $(p>0.05)$. Ammonia accumulation decreased $(p<0.01$ ) $23 \%$ in tannin-treated litter compared to the control $(2.8 \pm 0.1 \mu \mathrm{mol} / \mathrm{g})$. Conversely, the residual uric acid concentration was 1.6-fold higher $(p=0.02)$ in litter treated with the pine bark tannin than in the control litter. Urea concentrations were unaffected by tannin treatment $(p>0.05)$. Results suggest that pine bark tannin treatment may preserve uric acid and reduce ammonia volatilization in composted litter while aiding Salmonella control.

\section{INTRODUCTION}

Poultry litter can contain dangerous and unwanted pathogenic bacteria which could be resistant to antimicrobials and thus requires treatment before being fed. Composting is a practical method to process the litter; although total nitrogen $(\mathrm{N})$ can represent losses of about $59 \%$ of the initial concentration, and this occurs mainly due to $\mathrm{NH}_{3}$ volatilization, that can reduce the value of litter as a fertilizer and feed additive (Tiquia \& Tamb, 2000). Additions of biochar (BC) to poultry litter composted for fertilizer lowered $\mathrm{N}$ losses by $52 \%$ (Steiner et al., 2009), but it did not clear that the $\mathrm{N}$ fixed with $\mathrm{BC}$ can be used effectively by ruminants. Besides composting, chemical compounds such as sodium chlorate have been used to control pathogens in the gastrointestinal tract of ruminants (Anderson et al., 2002; Edrington et al., 2003; Callaway et al., 2003; Callaway et al., 2004: Anderson et al., 2005; Taylor et al., 2012; Arzola et al., 2014; Copado et al., 2014). Short-chain nitro compounds also have shown bactericidal effects on Salmonella spp., Escherichia spp. and other gastric and intestinal bacteria (Arzola-Alvarez et al., 2016; Arzola et al., 2017; Correa et al., 2017; Ruiz-Barrera et al., 2017).

Tannins are a distinct family of chemical compounds, having application in the food industry as well as in animal nutrition and 
Arzola-Alavarez C, Castillo-Castillo Y, Anderson RC, Hume ME, Ruiz-Barrera O, Min BR, Arzola-Rubio A, Beier RC,

Salinas-Chavira J

\section{Influence of Pine Bark Tannin on Bacterial Pathogens Growth and Nitrogen Compounds on Changes in Composted Poultry Litter}

\section{Analytical methods}

Tubes sampled at 0 and day 3 of incubation were serially diluted (10-fold) and plated to $3 M E$. colil coliform petri-film for enumeration of wildtype $E$. coli and to novobiocin- and naladixic acid- supplemented (20 and $25 \mu \mathrm{g} / \mathrm{mL}$, respectively) Brilliant Green Agar for quantitative recovery of the challenge STNN strain. E. coli/coliforms were counted according to $3 \mathrm{M}$ E. colil Coliform Petrifilm as per manufacturer's instructions (3M, Minneapolis, MN, USA). The initial 1:10 dilutions of each sample were also analyzed colorimetrically for the determination of uric acid using an Uric Assay Assay Kit (Sigma-Aldrich, St. Louis, MO, USA), urea using the QuantichromTM Urea Assay Kit (BioAssay Sysyems, Hayward, CA, USA). Ammonia was analyzed colorimetrically as described by Chaney \&Marbach, 1962). Total $\mathrm{N}$ was determined via combustion by the Soil, Water and Forage Testing Laboratory at the Texas AgriLife Extension Services' Department of Soil and Crop Sciences.

\section{Statistical Analysis}

Log base 10CFU of wildtype E. coli and STNN as well as uric acid, urea and ammonia concentrations were subjected to analysis of variance in a completely randomized design. Four treatments were considered: $\mathrm{T} 1$ no pine bark tannin and sampled at 0 days (control), T2 no pine bark tannin and sampled at 3 days, T3 pine bark tannin and sampled at 0 days, T4pine bark tannin and sampled at 3 days of composted poultry litter. Means of treatments were compared using the Least Significant Difference (LSD) test. Significant effect was considered at $p<0.05$.

\section{RESULTS}

The effect of pine bark tannin on Salmonella and E coli counts as uric acid, urea and ammonia concentrations in composted poultry litter are shown in Table 1. Salmonella typhimurium populations increased $(p<$ $0.01)$ as the days of composting increased; however, Pine bark tannin decreased $(p<0.01)$ STNN populations in the litter after $3 \mathrm{~d}$ of composting by $0.6 \mathrm{log}$ units compared to controls. Wild type E. coli populations were unaffected $(p>0.05)$ by tannin treatment but increased $(p<0.01)$ increasing days of composting.

Uric acid was higher and ammonia was lower $(p<0.01)$ in pine bark tannin-treated poultry litter after 3 days composting. On $0 \mathrm{~d}$ of incubation, these variables were not influenced ( $p>0.05)$ by pine bark tannin treatment. Urea concentrations were increased 
Arzola-Alavarez C, Castillo-Castillo Y, Anderson RC, Hume ME, Ruiz-Barrera O, Min BR, Arzola-Rubio A, Beier RC,

Salinas-Chavira J

\section{Influence of Pine Bark Tannin on Bacterial Pathogens Growth and Nitrogen Compounds on Changes in Composted Poultry Litter}

Table 1 - Effect of pine bark tannin on bacterial pathogens growth and nitrogen compounds in composed poultry litter $($ mean \pm SD)

\begin{tabular}{|c|c|c|c|c|c|}
\hline & \multicolumn{2}{|c|}{ Untreated } & \multicolumn{2}{|c|}{ Pine bark tannin } & \multirow[b]{2}{*}{$p$ value } \\
\hline & 0 Day & 3 Day & 0 Day & 3 Day & \\
\hline Uric Acid, $\mu \mathrm{mol} / \mathrm{g}$ & $20.90 \pm 3.32 a$ & $15.46 \pm 1.26 b$ & $20.90 \pm 3.32 a$ & $25.17 \pm 2.77 a$ & 0.02 \\
\hline Urea, $\mu \mathrm{mol} / \mathrm{g}$ & $3.49 \pm 0.55 b$ & $10.33 \pm 2.39 a$ & $3.49 \pm 0.55 b$ & $10.01 \pm 1.01 \mathrm{a}$ & $<0.01$ \\
\hline Ammonia, $\mu \mathrm{mol} / \mathrm{g}$ & $1.55 \pm 0.19 c$ & $2.82 \pm 0.11 a$ & $1.55 \pm 0.19 c$ & $2.15 \pm 0.14 b$ & $<0.01$ \\
\hline Salmonella typhimurium, $\log _{10} \mathrm{CFU} / \mathrm{g}$ & $3.89 \pm 0.04 c$ & $6.01 \pm 0.15 a$ & $3.89 \pm 0.04 c$ & $5.40 \pm 0.32 b$ & $<0.01$ \\
\hline Escherichia coli, $\log _{10}$ CFU/g & $5.29 \pm 0.39 b$ & $6.48 \pm 0.04 a$ & $5.29 \pm 0.39 b$ & $6.43 \pm 0.17 a$ & $<0.01$ \\
\hline
\end{tabular}

${ }^{a b c}$ In each row, values with different letter are statistically different $(p<0.05)$

$(p=0.02)$ due to days of composting but were unaffected $(p>0.10)$ by pine bark tannin treatment.

The effects of pine bark tannin on final $\mathrm{pH}$ and total nitrogen after 3 days composting poultry litter are showed In Table 2. Pine bark tannin had no influence $(p=0.23)$ on final $\mathrm{pH}$ and tended to greater $(p=0.09)$ total nitrogen in composted poultry litter.

Table 2 - Effect of pine bark tannin on final $\mathrm{pH}$ and total nitrogen after 3 days composting poultry litter (mean \pm SD)

\begin{tabular}{lcc}
\hline Treatment & $\mathrm{pH}$ & Total nitrogen $(\%)$ \\
\hline Untreated & $6.6 \pm 0.32$ & $3.06 \pm 0.07$ \\
Pine bark tannin & $6.3 \pm 0.15$ & $3.22 \pm 0.10$ \\
$p$ value & 0.23 & 0.09 \\
\hline
\end{tabular}

\section{DISCUSSION}

Salmonella typhimurium reduced populations in poultry litter treated with Pine bark tannin after $3 \mathrm{~d}$ of composted. Scalbert (1991) postulated that the antimicrobial activity of tannin could be attributed to inhibition of extracellular microbial enzymes with removal of substrates required for microbial growth or by direct effect on microbial metabolism inhibiting oxidative phosphorylation. Zdunczyk et al. (2018) observed that turkeys fed diets with faba bean seeds with high or low tannin content had a decrease in the counts of Salmonella bacteria in the gastrointestinal tract. Reyes et al. (2017) reported antibacterial effects against Salmonella infection in mice treated with tannin-derived components: gallic acid and tannic acid. Rubinelli et al. (2017) reported that sodium bisulfate alone or in a mixture with tannin reduced $S$. typhimurium rapidly of in vitro cultures of cecal and fecal samples of broiler chickens.

In the present study, E. coli populations were not inhibited by tannin treatment in composted poultry litter. However, Ribeiro et al. (2018) found that extract of different plants had inhibitory effects on the growth of $E$ coli. They observed that removing tannins from the extracts, the antimicrobial effect disappeared, indicating the importance of tannins on $E$. coli growth- inhibition. These differences could be due to the conditions in the culture of microorganisms. Ogawa \& Yazaki (2018) documented that E. coli was inhibited by tannin extracts only in aerobic conditions because tannins autoxidize releasing hydrogen peroxide inhibiting $E$. coli. This effect may not occur in anaerobic medium.

The increase in uric acid is consistent with ammonia reduction in the litter treated with pine bark tannin after 3 days composting. Uric acid is degraded to ammonia by microbial enzymes in the poultry manure. Manipulations of this process reduces ammonia volatilisation and nitrogen loses from poultry manure. In part, the conversion of uric acid to ammonia is attributed to microorganisms that use uric acid as a nitrogen source. Kim et al. (2006) found that poultry litter treated with nitrocompounds inhibited uric acidutilising microorganisms manure and Ruiz-Barrera et al. (2017) observed decreased rates of ammonia accumulation of more than $70 \%$ compared to untreated poultry manure. Further research on poultry litter treated with pine bark tannins on uric-acid utilising microorganisms is warrantied.

Tannins also reduce ammonia released in rumen through the reduction of dietary protein degraded by microorganisms in rumen due to the binding of tannins with proteins forming a complex of tannin-protein that is resistant to microbial enzymes in rumen (Naumann et al., 2017). Consistently pine bark tannins have reduced crude protein degradation with subsequent reduction in ammonia production in the rumen of goats (Min et al., 2012).

There is not information about chemical complexes formed among pine bark tannin with proteins or other nitrogen compounds of poultry manure.

Other effect of tannins is the methane reduction during rumen fermentation. Salami et al. (2018) observed that tannins inhibited methanogens or protozoa abundance in rumen fermentations. We have not found information about the influence of 
Arzola-Alavarez C, Castillo-Castillo Y, Anderson RC, Hume ME, Ruiz-Barrera O, Min BR, Arzola-Rubio A, Beier RC,

Salinas-Chavira J

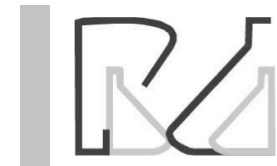

Influence of Pine Bark Tannin on Bacterial Pathogens Growth and Nitrogen Compounds on Changes in Composted Poultry Litter pine bark tannins on microbial fermentation related to methane production of composted poultry manure.

Urea concentrations were not influenced by pine bark tannin treatment; however, total nitrogen tended to be greater in poultry litter treated with pine bark tannin and may be related with the ammonia reduction and preservation of uric acid in the treated litter.

\section{CONCLUSIONS}

The reduction in ammonia production by pine bark tannins in the current study may be considered as a safe, environmentally compatible and sustainable technology to recycle nutrients contained in poultry litter for good animal production practices. Pine bark tannin treatment may be an attractive natural amendment to poultry litter to preserve the crude protein value of this feedstuff during early periods of composting while concurrently aiding in the reduction of pathogenic microbes. Further research into the effects of pine bark tannins on specific microorganisms and metabolites generated during composting poultry litter is warranted.

\section{ACKNOWLEDGEMENTS}

We acknowledge the Southern Plains Agricultural Research Center: USDA ARS at College Station for the loan of the facilities and technical staff in the present study.

\section{DECLARATION OF INTEREST STATEMENT}

No potential conflict of interest was reported by the authors

\section{REFERENCES}

Anderson RC, Callaway TR, Anderson TJ, Kubena LF, Keith NK, Nisbet DJ. Bactericidal effect of sodium chlorate on Escherichia coli concentrations in bovine ruminal and fecal contents in vivo. Microbial Ecology in Health and Disease 2002;14(1):24-29.

Anderson RC, Carr MA, Miller RK, King DA, Carstens GE, Genovese KJ, et al., Effects of experimental chlorate preparations as feed and water supplements on Escherichia coli colonization and contamination of beef cattle and carcasses. Food Microbiology 2005;22(5):439-447.

Arzola C, Copado R, Epps SVRP, Rodriguez-Almeida F, Ruiz-Barrera O, Rodriguez-Muela C, et al., Effects of repeated-low levelsodium chlorate administration on ruminal and fecal coliforms in sheep. Journal of Environmental Science and Health Part B 2014;49(12):966-970.

Arzola C, Ledezma-Perez EJ, Anderson R, Hume M, Ruiz-Barrera O, CorralLuna A, et al., Effects of nitro treatment on Salmonella, Escherichia coli, and nitrogen metabolism during composting of poultry litter. Journal of Animal Science 2017;95(suppl 4):24-24.
Arzola-Alvarez C, Corrales J, Ruiz-Barrera O, Anderson RC, Hume ME, Castillo-Castillo $Y$, et al., Short chain nitrocompounds treatment of poultry excreta; in vitro survivability of Salmonella, E. coli and nitrogen metabolism. Journal of Animal Science 2016;94(suppl 5):88-88.

Beauchemin KA, McGinn SM, Martinez TF. McAllister TA. Use of condensed tannin extract from quebracho trees to reduce methane emissions from cattle. Journal of Animal Science 2007;85(8):1990-1996.

Callaway TR, Anderson RC, Edrington TS, Bischoff KM, Genovese KJ Poole TL, Byrd JA, et al., Effects of sodium chlorate on antibiotic resistance in Escherichia coli 0157:H7. Foodborne Pathogens \& Disease 2004; 1(1):59-63.

Callaway TR, Edrington TS, Anderson RC, Genovese KJ, Poole TL, Elder RO, et al., Escherichia coli 0157:H7 populations in sheep can be reduced by chlorate supplementation. Journal of Food Protection 2003;66(2):194199

Chaney AL, Marbach EP. Modified reagents for determination of urea andammonia. Clinical Chemistry 1962;8(2):130-132.

Copado R, Arzola C, Epps SVR, Rodriguez-Almeida F, Ruiz O, RodriguezMuela $C$, et al., Effect of repeated suboptimal chlorate treatment on ruminal and fecal bacterial diversity. Journal of Food Protection 2014:77(9):1588-1592

Correa AC, Trachsel J, Allen HK, Corral-Luna A, Gutierrez-Bañuelos H, Ochoa-Garcia PA, et al., Effect of sole or combined administration of nitrate and 3-nitro-1-propionic acid on fermentation and Salmonella survivability in alfalfa-fed rumen cultures in vitro. Bioresource Technology 2017;229:69-77.

Dawson JM, Buttery PJ, Jenkins D, Wood CD, Gill M. Effects of dietary quebracho tannin on nutrient utilisation and tissue metabolism in sheep and rats. Journal of the Science of Food and Agriculture 1999;79(11):1423-1430.

Edrington TS, Callaway TR, Anderson RC, Genovese KJ, Jung YS, McReynolds JL, Bischoff KM, et al., Reduction of E. coli 0157:H7 populations in sheep by supplementation of an experimental sodium chlorate product. Small Ruminant Research 2003;49(2):173-181.

Kim WK, Anderson RC, Ratliff AL, Nisbet DJ, Ricke SC. Growth inhibition by nitrocompounds of selected uric acid-utilizing microorganisms isolated from poultry manure. Journal of Environmental Science and Health Part B 2006;41(1):97-107.

Kim WK, Weeks LJ, Anderson RC, Nisbet DJ, Dunkley K, Ricke SC. Effects of nitrocompounds on uric acid-utilizing microorganisms, nitrogen retention, and microbial community in laying hen manure. Journal of Environmental Science and Health Part B 2009;44(4):403-406.

Markou G. Improved anaerobic digestion performance and biogas production from poultry litter after lowering its nitrogen content. Bioresource Technology 2015;196:726-730.

Min BR, Solaiman S, Gurung N, Behrends J, Eun JS, Taha E, et al., Effects of pine bark supplementation on performance, rumen fermentation, and carcass characteristics of Kiko crossbred male goats. Journal of Animal Science 2012;90(10):3556-3567

Min BR, Solaiman S, Shange R, Eun JS. Gastrointestinal bacterial and methanogenic archaea diversity dynamics associated with condensed tannin-containing pine bark diet in goats using 16S rDNA amplicon pyrosequencing. International Journal of Microbiology 2014; 2014:141909.

Min BR, Solaiman S, Terrill T, Ramsay A, Mueller-Harvey I. The effects of tannins-containing ground pine bark diet upon nutrient digestion, nitrogen balance, and mineral retention in meat goats. Journal of Animal Science and Biotechnology 2015;6:25-32. 
Arzola-Alavarez C, Castillo-Castillo $Y$, Anderson RC, Hume ME, Ruiz-Barrera O, Min BR, Arzola-Rubio A, Beier RC,

Salinas-Chavira J

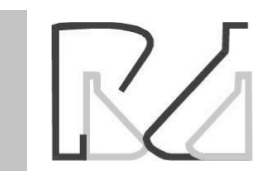

Influence of Pine Bark Tannin on Bacterial Pathogens

Growth and Nitrogen Compounds on Changes in

Composted Poultry Litter

Naumann HD, Tedeschi LO, Zeller WE, Huntley NF. The role of condensed tannins in ruminant animal production:advances, limitations and future directions. Revista Brasileira de Zootecnia 2017;46(12):929-949.

Ogawa S, Yazaki Y. Tannins from Acacia mearnsii De Wild. Bark: tannin determination and biological activities. Molecules 2018;23(4):18.

Reyes AWB, Hong TG, Hop HT, Arayan L, Huy TXN, Min W, Lee HJ, et al., The in vitro and in vivo protective effects of tannin derivatives against Salmonella entericaserovar Typhimurium infection. Microbial Pathogenesis 2017;109:86-93.

Ribeiro ICDO, Mariano EGA, Careli RT, Morais-Costa F, de Sant'Anna FM, Pinto MS, et al., Plants of the Cerrado with antimicrobial effects against Staphylococcus spp. and Escherichia coli from cattle. BMC Veterinary Research 2018;14(1):32.

Rubinelli PM, Kim SA, Park SH, Roto SM, Ricke SC. Sodium bisulfate and a sodium bisulfate/tannin mixture decreases $\mathrm{pH}$ when added to an in vitro incubated poultry cecal or fecal contents while reducing SalmonellaTyphimurium marker strain survival and altering the microbiome. Journal of Environmental Science and Health Part B 2017;52(8):607-615.

Ruiz-Barrera O, Anderson RC, Hume ME, Corrales-Millan J, Castillo-Castillo $Y$, Corral-Luna A, et al., Short chain nitrocompounds as a treatment of layer hen manure and litter; effects on in vitro survivability of Salmonella, generic $E$. coli and nitrogen metabolism. Journal of Environmental Science and Health Part B 2017;52(1):23-29.
Salami S, Valenti B, Bella M, Luciano G, O'Grady M, Kerry J, et al. Characterisation of the ruminal fermentation and microbiome in lambs supplemented with hydrolysable and condensed tannins. FEMS Microbiology Ecology 2018;94(5):61.

Scalbert A. Antimicrobial properties of tannins. Phytochemistry $1991 ; 30(12): 3875-3883$.

Steiner C, Das KC, Melear N, Lakly D. Reducing nitrogen loss during poultry litter composting using Biochar. Journal of Environmental Quality 2009;39(4):1236-1242

Taylor JB, Dungan RS, Lewis GS. Sodium chlorate reduces presence of Escherichia coli in feces of lambs and ewes managed in shed-lambing systems. Journal of Animal Science 2012;90(1):381-386.

Tiquia ST, Tamb NFY. Fate of nitrogen during composting of chicken litter. Environmental Pollution 2000;110(3):535-541.

Zdunczyk Z, Mikulski D, Jankowski J, Przybylska-Gornowicz B, Sosnowska E, Juskiewicz J, et al., Effects of dietary inclusion of high-and lowtannin faba bean (Vicia faba L.) seeds on microbiota, histology and fermentation processes of the gastrointestinal tract in finisher turkeys. Animal Feed Science and Technology 2018;240:184-196 
